Situs Jurnal : http://ejurnal.stiepancasetia.ac.id/index.php/jieb

Jilid 4 Nomor 3 November 2018

Hal 342 - 352

\title{
PENGARUH SHOPPING LIFESTYLE DAN MEDIA SOSIAL INSTAGRAM TERHADAP PEMBELIAN PRODUK SECARA ONLINE PADA WANITA BEKERJA DI BANJARMASIN
}

\section{Adista Anjar Diany*}

Abstract: Shopping lifestyle have significant role on creating purchase behavior consumer. The growing internet makes consumer use their mobile applications to searching information. Instagram is one of the choices for consumers to shop. This research tried to understand influence of shopping lifestyle and social media Instagram to purchase of product online on women working in Banjarmasin City, South Kalimantan. The population of this research are working wamen in Banjarmasin City, with 100 respondents woman and chosen with simple random sampling. The results of this research shows that shopping lifestyle and social media instagram simultaneously have a significant influence on purchase online, but partially only social media Instagram have a significant influence on purchase online.

Keywords: Shopping Lifestyle, Social Media, Instagram, Decision Purchase Online, Banjarmasin City

Abstrak: Faktor shopping lifestyle memiliki peran penting dalam menciptakan perilaku pembelian konsumen. Internet yang semakin berkembang membuat konsumen menggunakan aplikasi handphone dalam mencari informasi. Instagram menjadi salah satu sarana pilihan bagi konsumen dalam berbelanja. Penelitian ini mencoba untuk mengetahui pengaruh shopping lifestyle dan media sosial Instagram terhadap pembelian produk secara online pada wanita bekerja di Kota Banjarmasin, Kalimantan Selatan. Populasi penelitian ini adalah wanita bekerja yang tersebar di Kota Banjarmasin, dengan 100 orang diambil sebagai sampel dan dipilih dengan simple random sampling. Hasil penelitian menunjukkan bahwa shopping lifestyle dan media sosial Instagram secara simultan memiliki pengaruh positif yang signifikan terhadap keputusan pembelian online, namun secara parsial hanya media sosial Instagram yang memiliki pengaruh terhadap keputusan pembelian online pada wanita bekerja di Kota Banjarmasin.

Kata kunci : Fashion Lifestyle, Media Sosial, Instagram, Keputusan Pembelian Online, Kota Banjarmasin

\section{Latar Belakang}

Bagi masyarakat berbelanja telah menjadi lifestyle, masyarakat bahkan rela mengorbankan sesuatu demi mendapatkan produk yang mereka senangi. Hal ini dapat terlihat dari banyaknya pusat perbelanjaan yang ada disetiap kota. Namun, semakin sibuk dan keterbatasan waktu sehari-hari bagi seorang akan membuat mereka tidak terlalu sering berkunjung ke pusat perbelanjaan, karena itulah belanja online menjadi solusi yang sangat banyak dipilih oleh masyarakat. Selain mudah, belanja online juga dapat menghemat waktu konsumen dalam berbelanja. Konsumen hanya perlu memesan secara online dan barang atau produk akan datang langsung kerumah hanya dengan beberapa hari. 
Jumlah pengguna internet di Indonesia pada 1998 baru mencapai 500 ribu, namun ditahun 2017 telah mencapai lebih dari 100 juta. Pesatnya perkembangan teknologi, luasnya jangkauan layanan internet, serta makin murahnya harga gadget semakin membuat pengguna internet tumbuh cukup pesat. Menurut data survei APJII, pengguna internet di Indonesia pada 2017 telah mencapai 142 juta jiwa dengan penetrasi sebesar 54,69 persen dari total populasi. Pengakses internet pada tahun lalu tumbuh $7,9 \%$ dari tahun sebelumnya dan tumbuh lebih dari $600 \%$ dalam 10 tahun terakhir. Berbicara internet pada penjualan maka tapi lepas dengan kata online shop. Keberadaan online shop telah menjamur di Instagram seiring dengan semakin berkembangnya bisnis dan semakin meningkatnya kebutuhan pada konsumen. Berbelanja lewat internet merupakan suatu proses pembelian barang atau jasa dari mereka yang menjual melalui internet. Hanya perlu terhubung dengan internet untuk melakukan transaksi jual beli secara online ditambah banyaknya gadget atau smartphone yang bisa dan banyak digunakan untuk mengakses internet dimana saja dan kapan saja.

Shopping lifestyle didefinisikan sebagai perilaku yang ditujukan oleh pembeli sehubungan dengan serangkaian tanggapan dan pendapat pribadi tentang pembelian produk (Cobb dan Hoyer, 1986 dalam). Mereka menemukan bahwa shopping lifestye berkaitan erat dengan keputusan pembelian konsumen, hal yang sama juga disebutkan oleh Syahputra et. Al (2017), Syahputra juga menyebutkan saran untuk melakukan penelitian keputusan pembelian secara online karena. Penelitian yang dilakukan oleh Andini \& Wardoyo (2015) Shopping Lifestyle berpengaruh signifikan pembelian secara online, hal yang berbeda disebutkan oleh Zefanya Umboh, et.al. (2018).

Media sosial merupakan aplikasi atau sarana dimana konsumen mendapat hiburan dan mendapati berbagai promosi oleh pelaku bisnis didalamnya. Dalam media sosial terdapat halhal yang membuat konsumen tertarik untuk berbelanja berdasarkan beberapa hal, seperti konten yang menarik, komunikasi konsumen dengan penjual, hingga jumlah pengikut akun Instagram yang besar. Saat ini Instagram telah menjadi salah satu aplikasi paling diminati oleh para konsumen. Instagram merupakan platform social media yang paling mempengaruhi shopping habit konsumen. Selanjutnya diikuti oleh Facebook 23\%, Pinterest 22\%, Twitter $3 \%$, dan Snapchat 1\% didunia. Ditahun 2016, aplikasi Instagram menjadi aplikasi terbanyak yang paling sering digunakan dibanding aplikasi Facebook dan Path. Indonesia bahkan menjadi negara terbesar ketiga dengan jumlah pengguna aktif Instagram didunia Tahun 2018. Berdasarkan penelitian We Are Social, survei pada 2.000 orang pengguna instagram mengungkapkan bahwa $72 \%$ responden mengaku melakukan keputusan pembelian setelah mereka melihat produk di media sosial Instagram, dengan tingkat tertinggi $34 \%$ pembelian konsumen dilakukan pada produk fashion.

Wanita sering dijadikan target berbagai produk industry oleh pemasar karena karakteristik mereka yang lebih mudah terpengaruh dengan iklan, promosi dan berbagai strategi pemasaran. Fitria (2015) menyatakan bahwa adanya media sosial membuat penjualan suatu perusahaan dan pelaku shopping online meningkat karena keputusan pembelian secara online yang dilakukan oleh wanita, Fitria (2015) juga menyebutkan bahwa keputusan pembelian online yang dilakukan berdasarkan media sosial ini berpotensi penuh menimbulkan gaya pembelian konsumtif pada wanita. Dalam media sosial terdapat hal-hal yang membuat konsumen tertarik untuk berbelanja berdasarkan beberapa hal, seperti konten yang menarik, komunikasi konsumen dengan penjual, hingga jumlah pengikut akun Instagram yang besar. Mileva \& Fauzi (2018) menyebutkan bahwa tidak semua hal yang terdapat pada media sosial Instagram berpengaruh terhadap pembelian online.

Trend dan mode yang terjadi di sekitar wanita juga memengaruhi mereka untuk mengikuti kemajuan fashion saat ini. Wanita bekerja dikatakan lebih aktif berbelanja online melalui media sosial Instagram, kegiatan berbelanja online melalui Instagram ini menjadi hal keseharian dan dapat dikatakan sebuah gaya hidup konsumtif karena sudah biasa dilakukan, 
bahkan dilakukan secara terus menerus, berkelanjutan, dan menjadi ketergantungan. Gaya hidup akan ketertarikan akan berbelanja fashion, kebiasaan menggunakan media sosial Instagram dengan kemampuan dalam hal keuangan menjadikan wanita bekerja menjadi objek yang menarik untuk diteliti.

Berdasarkan uraian latar belakang diatas, permasalahan yang dirumuskan dan akan diteliti dalam penelitian ini adalah :

1. Apakah shopping lifestyle dan media sosial Instagram berpengaruh secara simultan terhadap keputusan pembelian produk online wanita bekerja di Banjarmasin Kalimantan Selatan?

2. Apakah shopping lifestyle dan penggunaan Instagram berpengaruh secara parsial terhadap keputusan pembelian produk online wanita bekerja di Banjarmasin Kalimantan Selatan?

\section{Kajian Literatur}

Gaya hidup (lifestyle) menunjukkan bagaimana orang hidup, bagaimana mereka membelanjakan uangnya, dan bagaimana mereka mengalokasikan waktu mereka (Mowen dan Minor, 2002). Kebutuhan konsumen sangat berpengaruh pada gaya hidup atau lifestyle, kegiatan berbelanja menjadi salah satu tempat yang paling digemari oleh seseorang untuk memenuhi kebutuhannya. Terkadang kegiatan berbelanja dilatar belakangi oleh pola konsumsi seseorang untuk menghabiskan waktu dan uang dan berbelanja menjadi sebuah gaya hidup, kemungkinan besar shopping lifestyle ini yang menyebabkan terjadinya pembelian secara implusif baik secara langsung ataupun melalui online (Kosyu, et. al, 2014:3).

Semakin sibuk dan keterbatasan waktu sehari-hari bagi seorang akan membuat mereka tidak terlalu sering berkunjung ke pusat perbelanjaan, karena itulah belanja online menjadi solusi yang sangat banyak dipilih oleh masyarakat. Selain mudah, belanja online juga dapat menghemat waktu konsumen dalam berbelanja. Konsumen hanya perlu memesan secara online dari mana dan kapan saja kemudian barang atau produk akan datang langsung kerumah hanya dengan beberapa hari saja.

Konsumen Indonesia menyukai belanja online seiring dengan meningkatnya penetrasi Internet di Indonesia. Mereka senang membaca ulasan dan mencari informasi mengenai produk dan jasa yang dibutuhkan. Menurut laporan itu, Indonesia berada dalam urutan teratas secara global dalam hal penggunaan ponsel untuk belanja online bersama dengan Filipina, Vietnam, dan Thailand. Menurut 2018 Global Review produk yang paling sering dibeli online oleh konsumen adalah fashion diikuti dengan pembelian gadget, alat elektronik, buku dan majalah serta bahan makanan dengan Perangkat yang paling sering digunakan untuk berbelanja online adalah telepon seluler.

Berdasarkan pada pendapat Cobb dan Hoyer (1986) dalam Tirmizi, et.al (2009;527), maka bisa dirinci indikator dari shopping lifestyle adalah sebagai berikut: 1) Berbelanja merupakan kegiatan rutin untuk memenuhi semua kebutuhan. 2) Berbelanja merupakan kegiatan sosial untuk bisa berhubungan dengan orang lain. 3) Berbelanja dengan memilih tempat berbelanja menunjukkan status sosial konsumen. 4) Terdapat perencanaan secara periodik untuk berbelanja. 5) Belanja merupakan aktivitas yang menyenangkan.

Instagram telah menjadi salah satu aplikasi paling diminati oleh para konsumen. Instagram merupakan platform social media yang paling mempengaruhi shopping habit konsumen. Instagram banyak diminati semua kalangan tanpa terkecuali masyarakat, artis, pejabat, perusahan dan bahkan para pemilik online shop. Belanja online lewat internet merupakan suatu proses pembelian barang atau jasa dari mereka yang menjual melalui internet. Hanya perlu terhubung dengan internet untuk melakukan transaksi jual beli secara online ditambah banyaknya gadget atau smartphone yang bisa dan banyak digunakan untuk mengakses internet dimana saja dan kapan saja. 
Menurut Philip Kotler dan Kevin Keller (2012:568), media sosial merupakan sarana bagi konsumen untuk berbagi informasi teks, gambar, audio dan video dengan satu sama lai dan dengan perusahaan dan sebaliknya. Media sosial memungkinkan pelanggan dan calon pelanggan yang prospek untuk berkomunikasi langsung berkaitan dengan produk yang dijual secara online dengan rekan-rekannya yang lain sehingga produk tersebut semakin dikenal oleh banyak orang.

Media sosial adalah sebuah fenomena baru yang telah mengubah cara lingkungan bisnis beroperasi. Melalui media sosial, bisnis mendapatkan akses berkaitan dengan sumber daya yang dinyatakan tidak tersedia bagi pemilik bisnis. Hal ini juga dapat membantu perusahaan untuk meningkatkan kelayakan mereka, memupuk kemitraan strategis dan meningkatkan kontak mereka dengan pelanggan dan pemasok. Bagi pemilik bisnis, media sosial menjadi peran penting untuk melakukan pemasaran dan mengembangkan usahanya agar mencakup konsumen yang lebih luas.

Penggunaan sosial media saat ini sudah berhubungan dengan aktivitas e-commerce, dimana perusahaan menginginkan perubahan dari "trying to sell" menjadi "making connection" dengan konsumen. Instagram menjadi sarana informasi berbagai kebutuhan konsumen, sehingga informasi menjadi salah satu dimensi dalam penggunaan media social Instagram.

Menurut penelitian dari Hauer (dalam Solis, 2011: 263) terdapat dimensi dalam penggunaan social media yaitu:

1. Content, adalah bagaimana membentuk sebuah pesan atau cerita (informasi). Konten dalam penggunaan media social Instagram biasanya dikaitkan dengan mudahnya penggunaan aplikasi yang bersangkutan. Dalam bisnis berbagi konten dapat menyebabkan penjualan tidak langsung dan langsung tergantung pada jenis konten yang dibagikan. Hal ini dapat mendasari adanya keputusan pembelian oleh konsumen terhadap belanja online.

2. Communication, "The practice of sharing our story as well as listening, responding, and growing”. Komunikasi merupakan cara berbagi cerita atau informasi yang meliputi cara mendengarkan, merespon, dan menumbuhkan informasi.

3. Collaboration, "Working together to make things better and more efficient and effective" Kerja sama antara pengguna social media untuk membuat hal baik yang lebih efektif dan efisien.

4. Connection, "The relationships we forge and maintain" Yaitu pemeliharaan hubungan yang sudah terbina. Media Sosial memungkinkan seseorang bertemu dengan lebih banyak orang yang memiliki minat yang sama. Jaringan yang luas dapat membangun hubungan yang dapat menghasilkan lebih banyak bisnis dan kemungkinan terjadinya transaksi penjualan.

5. Continuity, "Providing an on going, valuable, and consistent user experience" Adalah menyediakan informasi dan pengalaman yang terus menerus, bernilai dan secara konsisten pada khalayak.

Indonesia merupakan pengguna internet terbesar di Asia Tenggara. Internet di Indonesia saat ini sudah menjadi kebutuhan primer untuk para penggunanya, perkembangan media sosial juga menjadi salah satu faktor penting besarnya pemakai internet di Indonesia. Media sosial juga kini dijadikan fasilitas untuk memulai usaha dengan segala bidang yaitu salah satunya melalui media sosial Instagram. Instagram adalah sebuah aplikasi berbagi foto yang memungkinkan pengguna mengambil foto, menerapkan filter digital, dan membagikannya ke berbagai layanan sosial media. Penggunaan media sosial Instagram yang berisikan konten, kemudahan, kenyaman berkomunikasi dan penggunaan berkelanjutan yang menyenangkan membuat konsumen wanita semakin menyukai berselancar tentang produk fashion secara online. 

berikut:

Berdasarkan kajian yang telah diuraikan diatas maka dapat disusun hipotesis sebagai

H1 : Shopping Lifestyle dan Media Sosial Instagram Berpengaruh secara Simultan Terhadap Keputusan Pembelian Produk Online pada Wanita Bekerja di Banjarmasin.

H2 : Shopping Lifestyle Berpengaruh secara signifikan Terhadap Keputusan Pembelian Produk Online pada Wanita Bekerja di Banjarmasin.

H3 : Media Sosial Instagram Berpengaruh secara signifikan Terhadap Keputusan Pembelian Produk Online pada Wanita Bekerja di Banjarmasin

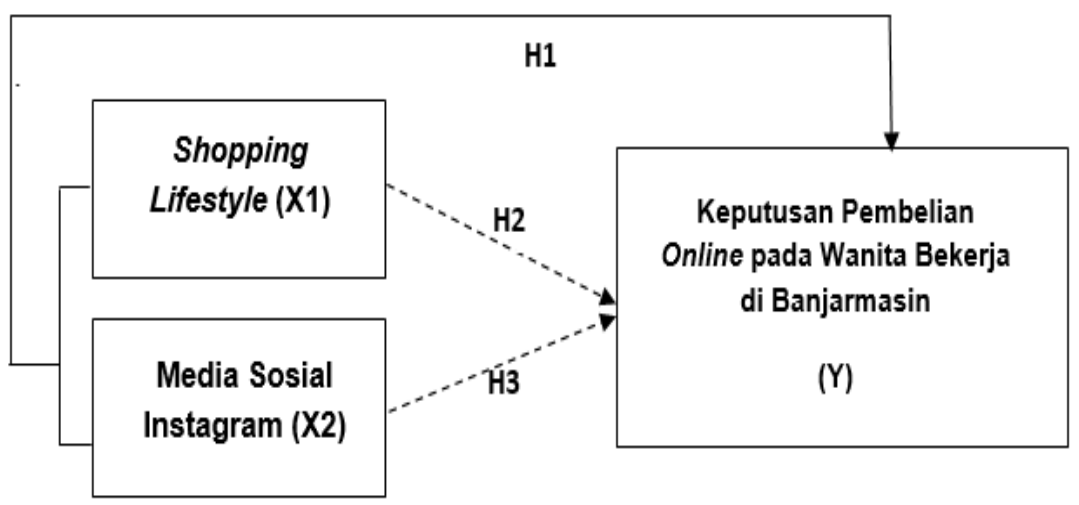

Gambar 1. Kerangka Pikir Penelitian

\section{Metode Penelitian}

Penelitian ini termasuk dalam kategori penelitian kuantitatif asosiatif, karena penelitian ini memandang bahwa realitas/gejala/fenomena dapat diklasifikasikan, relative tetap, konkrit, teramati, terukur dan menunjukkan gejala sebab akibat (Sugiyono, 2013:95). Sedangkan dikatakan asosiatif karena dari tingkat penjelasannya penelitian ini mencoba meneliti hubungan antara dua variabel atau lebih (Sugiyono, 2013:95).

Populasi dalam penelitian ini adalah wanita bekerja yang berdomisili di Kota Banjarmasin. Jumlah data penduduk Banjarmasin berjenis kelamin wanita ditahun 2017 adalah sebanyak 345.385 orang dengan Jumlah lowongan kerja yang terdaftar dan penempatan kerja sebesar 539 orang wanita (Sumber: Dinas Koperasi, Usaha Mikro dan Tenaga Kerja Kota Banjarmasin).

Sampel adalah bagian dari jumlah dan karakteristik yang dimiliki oleh populasi. Menurut Arikunto (2013:116) "Penentuan pengambilan sampel sebagai berikut : Apabila kurang dari 100 lebih baik diambil semua hingga penelitiannya merupakan penelitian populasi. Jika jumlah subjeknya besar dapat diambil antara $10-15 \%$ atau $20-55 \%$ atau lebih tergantung sedikit banyaknya dari kemampuan peneliti dilihat dari waktu, tenaga dan dana. Berdasarkan hal tersebut maka peneliti memutuskan jumlah sampel sebanyak $20 \%$ dari total 539 adalah 107,8 dibulatkan kebawah menjadi 100 responden.

\section{Hasil Penelitian dan Pembahasan}

Jumlah wanita yang dijadikan responden dalam penelitian ini berjumlah 100 orang. Tabel 6 menunjukkan nilai rata-rata variabel shopping lifestyle sebesar 3,96. Temuan ini menunjukkan Hal ini menunjukkan bahwa responden sering menanggapi tawaran iklan online. Responden menyatakan sering mengunjungi situs atau akun yang diiklankan via online. Responden mengaku sering mendapati barang atau produk yang menarik berdasarkan iklan tersebut. Hal ini menjadi suatu masukan bagi pemasar bahwasanya promosi produk berupa iklan tetap tidak bisa dipisahkan bagi strategi penjualan suatu produk. 
Diany, Pengaruh Shopping Lifestyle dan Media Sosial Instagram Terhadap Pembelian Produk Secara .

Tabel 1. Deskripsi Jawaban Responden Variabel Shopping Lifestyle

\begin{tabular}{|c|c|c|c|c|c|c|}
\hline \multirow{3}{*}{ Indikator Pernyataan } & \multicolumn{5}{|c|}{ Jawaban Responden } & \multirow{3}{*}{$\begin{array}{l}\text { Rata- } \\
\text { Rata }\end{array}$} \\
\hline & 1 & 2 & 3 & 4 & 5 & \\
\hline & $F(\%)$ & $F(\%)$ & $F(\%)$ & $F(\%)$ & $F(\%)$ & \\
\hline Menanggapi tawaran iklan berbelanja produk fashion online & 5 & 2 & 6 & 16 & 71 & 4.46 \\
\hline Tertarik berbelanja produk fashion dengan model terbaru & 8 & 12 & 15 & 24 & 41 & 3.78 \\
\hline Berbelanja produk fashion lebih dari satu merek & 4 & 9 & 24 & 22 & 41 & 3.87 \\
\hline Terdapat fashion merk lain yang sama kualitasnya & 4 & 8 & 14 & 14 & 60 & 4.18 \\
\hline Berbelanja produk fashion yang memiliki kualitas terbaik & 5 & 14 & 15 & 30 & 36 & 3.78 \\
\hline Berbelanja barang atau merek yang terkenal & 2 & 10 & 15 & 37 & 36 & 3.95 \\
\hline Belanja sebagai sarana untuk mengikuti trend fashion & 1 & 6 & 16 & 48 & 29 & 3.98 \\
\hline Merasa nyaman pada saat berbelanja & 0 & 0 & 28 & 56 & 16 & 3.88 \\
\hline Menikmati waktu berbelanja meski tidak melakukan pembelian & 2 & 9 & 17 & 44 & 28 & 3.87 \\
\hline Berbelanja adalah pengalaman yang menyenangkan & 0 & 5 & 24 & 53 & 18 & 3.84 \\
\hline Rata-Rata Variabel Fashion Lifestyle & 3.1 & 7.5 & 17.4 & 34.4 & 37.6 & 3.96 \\
\hline
\end{tabular}

Tabel 2. Karakteristik Jawaban Responden Variabel Media Sosial Instagram

\begin{tabular}{|c|c|c|c|c|c|c|}
\hline \multirow{3}{*}{ Indikator Pernyataan } & \multicolumn{5}{|c|}{ Jawaban Responden } & \multirow{3}{*}{$\begin{array}{l}\text { Rata- } \\
\text { Rata }\end{array}$} \\
\hline & 1 & 2 & 3 & 4 & 5 & \\
\hline & $\mathbf{F}(\%)$ & $\mathbf{F}(\%)$ & $\mathbf{F}(\%)$ & $F(\%)$ & $\mathbf{F}(\%)$ & \\
\hline Instagram menyediakan kebutuhan informasi trend fashion terbaru & 6 & 7 & 12 & 20 & 55 & 4.11 \\
\hline Kemudahan akses Instagram membantu memahami produk & 2 & 7 & 24 & 19 & 48 & 4.04 \\
\hline Kemudahan melakukan transaksi online menggunakan Instagram & 2 & 8 & 17 & 46 & 27 & 3.88 \\
\hline Instagram sebagai sarana komunikasi & 2 & 2 & 20 & 45 & 31 & 4.01 \\
\hline Membaca testimoni orang lain tentang produk di online shop & 1 & 4 & 12 & 46 & 37 & 4.14 \\
\hline Bisnis dalam media sosial merupakan hal yang penting & 2 & 8 & 22 & 41 & 27 & 3.83 \\
\hline Instagram adalah alat pemasaran yang baik untuk berpromosi & 2 & 8 & 15 & 34 & 41 & 4.04 \\
\hline Instagram memenuhi kebutuhan berbelanja jelajah timeline online sh & 6 & 11 & 18 & 36 & 29 & 3.71 \\
\hline Media sosial Instagram memudahkan pembelian & 1 & 9 & 18 & 44 & 28 & 3.89 \\
\hline Instagram menghubungkan dengan produk atau merek & 2 & 10 & 14 & 45 & 29 & 3.89 \\
\hline Instagram merupakan pengisi waktu luang & 3 & 5 & 23 & 41 & 28 & 3.86 \\
\hline Merasa bosan apabila tidak mengakses aplikasi Instagram & 2 & 7 & 14 & 46 & 31 & 3.97 \\
\hline Berbelanja fashion melalui Instagram memiliki kemungkinan produk & 1 & 6 & 16 & 48 & 29 & 3.98 \\
\hline Rata-Rata Variabel Media Sosial Instagram & 2.5 & 7.1 & 17.3 & 39.3 & 33.8 & 3.95 \\
\hline
\end{tabular}

Tabel 2 menunjukkan nilai rata-rata variabel media sosial Instagram sebesar 3,96. Temuan ini menunjukkan konsumen menyukai aktivitas dengan akun Instagram yang mereka miliki, berselancar pada aplikasi Instagram dirasa hal yang menyenangkan bagi konsumen. Dalam tanya jawab atau interview, responden juga menyebutkan bahwa komunikasi dan pengetahuan akan produk secara lengkap ada pada feed setiap akun Instagram, hal ini tentunya memudahkan konsumen dalam berbelanja. Konsumen menyukai merek yang mereka pilih memiliki akun khusus pada Instagram sehingga memungkinkan mereka untuk semakin dekat dengan produk dan mengetahi berbagai informasi tentang produk atau merek.

Tabel 3 menunjukkan nilai rata-rata variabel keputusan pembelian online sebesar 3,96. Berdasarkan Tabel diatas, menunjukan bahwa pendapat responden didominasi oleh jawaban setuju sebesar 50\%. Hal ini menandakan bahwa wanita berusaha untuk mendapatkan informasi terbaru tentang produk fashion dan berbelanja melalui Instagram, wanita juga mengakui bahwa merasa puas memilih media sosial sebagai tempat berbelanja online, hal ini 
dapat dilihat pada jawaban responden dipertanyaan kedua dengan dominasi jawaban setuju sebesar 58\%. Konsumen merasa pembelian online dapat dipertanggung jawabkan kualitasnya dan masih merasa aman berbelanja fashion melalui Instagram.

Tabel 3. Karakteristik Jawaban Responden Variabel Keputusan Pembelian Online

\begin{tabular}{|c|c|c|c|c|c|c|}
\hline \multirow{3}{*}{ Indikator Pernyataan } & \multicolumn{5}{|c|}{ Jawaban Responden } & \multirow{3}{*}{$\begin{array}{l}\text { Rata- } \\
\text { Rata }\end{array}$} \\
\hline & 1 & 2 & 3 & 4 & 5 & \\
\hline & $F(\%)$ & $\mathbf{F}(\%)$ & $F(\%)$ & $F(\%)$ & $F(\%)$ & \\
\hline Berusaha mendapatkan informasi terbaru tentang produk fashion melalui Instagram & 0 & 4 & 20 & 50 & 26 & 3.98 \\
\hline Kepuasan memilih media sosial sebagai tempat berbelanja online & 0 & 1 & 17 & 58 & 24 & 4.05 \\
\hline Pembelian online dapat dipertanggung jawabkan kualitasnya & 0 & 3 & 13 & 54 & 30 & 4.11 \\
\hline Keamanan dalam berbelanja fashion melalui Instagram & 0 & 3 & 20 & 54 & 23 & 3.97 \\
\hline Interaksi dengan penjual secara online bermanfaat dalam memutuskan pembelian & 0 & 5 & 25 & 51 & 19 & 3.84 \\
\hline Rata-Rata Variabel Keputusan Pembelian Online & 0 & 3.2 & 19 & 53.4 & 24.4 & 3.99 \\
\hline
\end{tabular}

Selanjutnya dilakukan uji validitas dan reliabilitas. Dalam uji validitas syarat minimum yang dianggap memenuhi syarat atau dikatakan valid adalah kalau $r=0,3$, jadi kalau korelasi antara butir-butir skor total kurang dari 0,3 dinyatakan tidak valid (Sugiyono, 2013:151). Uji validitas ini ditunjuk untuk mengetahui apakah kuesioner yang diajukan layak atau tidak. Sedangkan uji reliabilitas membandingkan antara nilai alpha cronbach (ra) dengan r tabel, dimana nilai alpha cronbach (ra) lebih besar dari nilai $r$ tabel. Suatu konstruk atau variabel dikatakan reliabel jika memberikan nilai alpha cronbach > 0,60 (Ghozali, 2014:95). Hasil uji vaiditas dan reliabilitas ditunjukkan pada tabel 4.

Tabel 4. Hasil Uji validitas dan reliabilitas Shopping Lifestyle

\begin{tabular}{ccc} 
Item & Korelasi (r) & Alpha cronbach \\
\hline Item 1 & 0,547 & \\
Item 2 & 0,514 & \\
Item 3 & 0,544 & \\
Item 4 & 0,392 & \\
Item 5 & 0,482 & \\
Item 6 & 0,514 & \\
Item 7 & 0,499 & \\
Item 8 & 0,306 & \\
Item 9 & 0,446 & \\
Item 10 & 0,480 & \\
\hline
\end{tabular}

Dari tabel 4 dapat dilihat bahwa nilai korelasi (r) item 1 s.d 10 lebih besar dari 0,3, sehingga kesepuluh butir pertanyaan dinyatakan valid, demikian juga dengan nilai alpha cronbach lebih besar dari syarat $(0,6)$ yaitu $(0,609)$ sehingga kuesioner dinyatakan reliabel.

Tabel 5. Hasil Uji validitas dan reliabilitas Media Sosial Instagram

\begin{tabular}{|c|c|c|c|}
\hline \multicolumn{2}{|c|}{ ItEenen } & $I=0+1=I=2=-i$ & 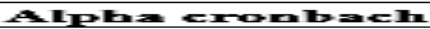 \\
\hline Ite=me & 11 & 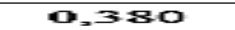 & \\
\hline Iteran I I I & $1 \geq$ & $m_{3}=15$ & \\
\hline Iteman & 13 & 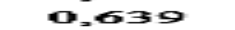 & \\
\hline Iterar & $1=$ & $\square=67$ & \\
\hline Iteman & 15 & $x_{-} \rightarrow 3$ & \\
\hline Itentan & $1 \approx$ & $a_{=}=11$ & \\
\hline Iteman & $1=$ & 0.35 & $0:=32$ \\
\hline Item & $1=$ & $\square=37$ & \\
\hline Iterar & 10 & $\min 5$ & \\
\hline Itema = & $\geq$ & $\square=5 \leq 5$ & \\
\hline Etener. = & $\geq 1$ & 0516 & \\
\hline Iteran = & $2 \geq$ & $0 . \operatorname{sen} 0$ & \\
\hline$I t=m=$ & $\geq 3$ & $\square=-9$ & \\
\hline
\end{tabular}

Dari tabel 5 dapat dilihat bahwa nilai korelasi (r) item 11 s.d 23 lebih besar dari 0,3, sehingga ketiga belas butir pertanyaan dinyatakan valid, demikian juga dengan nilai alpha cronbach lebih besar dari syarat $(0,6)$ yaitu $(0,732)$ sehingga kuesioner dinyatakan reliabel. 
Tabel 6. Hasil Uji validitas dan reliabilitas Keputusan Pembelian Online

\begin{tabular}{ccc}
\hline Item & Korelasi & Alpha cronbach \\
\hline Item 24 & 0,723 & \\
Item 25 & 0,638 & \\
Item 26 & 0,709 & 0,701 \\
Item 27 & 0,628 & \\
Item 28 & 0,677 & \\
\hline
\end{tabular}

Dari tabel 6 dapat dilihat bahwa nilai korelasi (r) item 24 s.d 28 lebih besar dari 0,3, sehingga ketiga belas butir pertanyaan dinyatakan valid, demikian juga dengan nilai alpha cronbach lebih besar dari syarat $(0,6)$ yaitu $(0,701)$ sehingga kuesioner dinyatakan reliabel.

Tabel 7. Rangkuman Hasil Uji Asumsi Klasik

\begin{tabular}{lccccc}
\hline \multirow{2}{*}{\multicolumn{1}{c}{ Variabel }} & \multicolumn{2}{c}{ Uji Multikolinearitas } & $\begin{array}{c}\text { Uji Heteros- } \\
\text { kedastisitas }\end{array}$ & $\begin{array}{c}\text { Uji } \\
\text { Linearitas }\end{array}$ & $\begin{array}{c}\text { Uji } \\
\text { Normalitas }\end{array}$ \\
\cline { 2 - 6 } & Tolarance & VIF & Sig & Sig & Asymp. Sig. \\
\hline Shopping Lifestyle (X1) & 0,625 & 1,599 & 0,124 & 0,019 & 0,231 \\
Media Sosial Instagram (X2) & 0,625 & 1,599 & 0,710 & 0,000 & \\
\hline
\end{tabular}

Berdasarkan hasil Uji Asumsi klasik, dapat terlihat bahwa hasil analisis telah memenuhi syarat. Uji multikolinieritas dilihat dari nilai toleransi variabel dengan syarat dan Variance Inflation Factor (VIF), Nilai tolerance X1 $(0,625)$ dan X2 $(0,625)$ yang lebih kecil dari nilai syarat 1 serta nilai VIF X1 $(1,599)$ dan X2 $(1,599)$ lebih besar dari nilai syarat 0,1 . Uji Heterokedastisitas pada penelitian ini menggunakan uji glejser, dengan hasil output nilai signifikan dari setiap variabel independen yaitu (X1) dan (X2) lebih besar dari 0,05 yang berarti setiap variabel independen tidak terjadi gejala heteroskedastisitas. Pada uji linearitas, kriteria yang digunakan yaitu garis regresi dikatakan linear jika nilai linearity lebih kecil dari $5 \%$ (0,05). Berdasarkan hasil yang didapat, setiap variabel independen lebih besar dari 0,05 yang berarti setiap variabel independen garis regresinya dikatakan linear.

Kriteria untuk mendeteksi uji normalitas dengan menggunakan uji kolmogorovSmirnov, nilai signifikan (2-tailed) adalah 0,231 lebih besar dari 0,05 yang berarti residual tidak mengalami gangguan distribusi normal.

Apabila sudah dilakukan uji asumsi klasik dengan nilai yang telah memenuhi syarat maka dapat selanjutnya menggunakan analisis data penelitian, dalam penelitian ini menggunakan analis regresi berganda.

Tabel 8. Rangkuman Hasil Analisis Regresi Berganda

\begin{tabular}{llcccc}
\hline \multicolumn{1}{c}{$\begin{array}{c}\text { Variabel } \\
\text { Terikat }\end{array}$} & \multicolumn{1}{c}{ Variabel Bebas } & $\begin{array}{c}\text { Koefisien } \\
\text { Regresi }\end{array}$ & $\mathbf{t}_{\text {hitung }}$ & $\mathbf{r}_{\text {partial }}$ & Sig \\
\hline $\begin{array}{l}\text { Keputusan } \\
\begin{array}{l}\text { Pembelian } \\
\text { Online }(\mathrm{Y})\end{array}\end{array}$ & Fashion Lifestyle $\left(\mathrm{X}_{1}\right)$ & $-0,013$ & $-0,225$ & $-0,023$ & 0,823 \\
\cline { 2 - 6 } & Media Sosial Instagram $\left(\mathrm{X}_{2}\right)$ & 0,170 & 3,652 & 0,348 & 0,000 \\
\hline Konstanta & $=$ & 11,777 & Adjusted R Square & $=$ & 0,152 \\
\hline $\mathrm{t}_{\text {tabel }}$ & $=$ & 1,66071 & $\mathrm{~F}_{\text {hitung }}$ & $=$ & 9.902 \\
\hline Multiple R & $=$ & 0,412 & Sig F & $=$ & 0,000 \\
\hline
\end{tabular}

Berdasarkan rangkuman hasil output SPSS pada Tabel 8, dapat diketahui nilai $\mathrm{F}$ hitung adalah 9,902 dengan angka Sig. 0,000. Nilai pembilang pada penelitian diketahui adalah 2 dan angka penyebut adalah 97, sehingga didapatkan nilai Ftabel sebesar 3,09. Dari perbandingan Fhitung dengan Ftabel dapat diketahui bahwa angka Fhitung ternyata lebih besar dari Ftabel $(9,902>3,09)$, dengan demikian terbukti bahwa semua variabel independen $(\mathrm{X})$ memberikan 
pengaruh secara simultan terhadap variabel dependen (Y). Hal itu juga dilihat berdasarkan nilai sig. F sebesar 0,000 berada di bawah $0,05(0,000<0,05)$. Dengan demikian hipotesis penelitian pertama yang menyatakan bahwa: shopping lifestyle dan media sosial instagram secara simultan berpengaruh signifikan terhadap Keputusan pembelian produk online wanita bekerja di Banjarmasin dapat diterima.

Kedua variabel independent yaitu shopping lifestyle dan media sosial instagram mempunyai hubungan yang sedang (Sugiyono, 2013: 250) dengan Keputusan pembelian produk online pada wanita bekerja, hal ini dilihat dari Multiple $R$ yaitu sebesar 0,412 . Selanjutnya besarnya pengaruh variabel independen terhadap variabel dependen berdasarkan dari nilai adjusted $R$ square sebesar 0,152 . Nilai koefisien tersebut menunjukan bahwa besarnya pengaruh yaitu shopping lifestyle dan media sosial instagram secara simultan terhadap Keputusan pembelian produk online pada wanita bekerja di Banjarmasin sebesar 15,2\%, sedangkan sisanya 84,8\% dipengaruhi oleh variabel lain yang tidak diteliti dalam penelitian ini. Hal ini menjadi masukkan bahwa masih banyak faktor-faktor lain shopping lifestyle terhadap keputusan pembelian online yang dapat diteliti berikutnya. Dengan demikian, dapat disimpulkan bahwa hipotesis yang menyatakan shopping lifestyle dan media sosial instagram berpengaruh secara simultan terhadap Keputusan pembelian produk online pada wanita bekerja di Banjarmasin, sehingga secara statistik terbukti $\mathrm{H} 1$ diterima.

Uji parsial dilihat pada nilai $\mathrm{t}$, nilai $\mathrm{t}$ memiliki probabilitas masing-masing faktor tersebut lebih kecil dari tingkat alpha $(\alpha)=0,05$ maka dinyatakan bahwa variabel bebas tersebut berpengaruh terhadap variabel terikat, jika thitung kurang dari ttabel maka hipotesis kedua ditolak (Sanusi, 2015:22).

1. Shopping Lifestyle (X1), memiliki nilai thitung sebesar -0,225 dan tingkat signifikan sebesar 0,823. Hal tersebut menunjukkan bahwa (X1) tidak berpengaruh signifikan terhadap (Y). Pembuktian dari pernyataan tersebut adalah berdasarkan nilai thitung yang lebih kecil dari nilai ttabel $(-0,225<1,66071)$ dan besarnya nilai signifikan yang lebih tinggi dari taraf signifikan $(0,823>0,05)$. Berdasarkan hal tersebut, maka hipotesis penelitian pertama yang menyatakan bahwa: Shopping Lifestyle berpengaruh signifikan terhadap keputusan pembelian produk online pada Wanita Bekerja di Banjarmasin. Dengan demikian, dapat disimpulkan bahwa hipotesis $\mathrm{H} 2$ tidak dapat diterima.

2. Media Sosial Instagram (X2) memiliki nilai thitung sebesar 3,652 dan tingkat signifikan sebesar 0,000. Hal tersebut menunjukkan (X2) berpengaruh signifikan terhadap (Y). Pembuktian dari pernyataan tersebut adalah berdasarkan nilai thitung yang lebih besar dari nilai ttabel $(3,652<1,66071)$ dan besarnya nilai signifikan yang lebih rendah dari taraf signifikan $(0,000>0,05)$. Berdasarkan hal tersebut, maka hipotesis penelitian kedua yang menyatakan bahwa Media Sosial Instagram (X2) berpengaruh signifikan terhadap Keputusan Pembelian Produk Online pada Wanita Bekerja di Banjarmasin dapat diterima. Dengan demikian, dapat disimpulkan bahwa hipotesis H3 diterima.

Hasil penelitian ini menolak hasil penelitian dari Andini \& Wardoyo (2015) yang menyatakan bahwa shopping lifestyle berpengaruh signifikan terhadap keputusan pembelian secara online namun senada dan mendukung hasil penelitian dari Zefanya Umboh, et.al. (2018).Jika dilihat secara umum hasil variabel shopping lifestyle, rata-rata responden menjawab positif dengan jawaban terbanyak diskala :sangat setuju" atau "setuju". Namun masih ada beberapa responden yang menjawab netral atau "cukup setuju". Hasil penelitian secara empiris dengan SPSS membuktikan bahwa shopping lifestyle tidak berpengaruh signifikan terhadap disiplin kerja pegawai dengan keterangan thitung $<$ ttabel yaitu $-0,225<$ 1,66071 dan nilai sig. 0,823>0,05. Dengan demikian hipotesis dalam penelitian ini yaitu $\mathrm{H} 2$ ditolak. Hal ini tentunya menjadi pukulan telak kepada para pemasar atau marketer, karena pada dasarnya berbagai macam produk yang dibuat atau dihasilkan berawal dari adanya kebutuhan dan sifat manusia yang kebanyakan menyukai kegiatan berbelanja dan rasa haus 
akan pemenuhan penampilan. Hal ini sebaiknya dapat dikaji ulang oleh para marketer, dengan hasil penelitian ini didapat kenyataan bahwa ditengah gempuran konsumtifnya konsumen, ternyata masih ada konsumen yang melakukan pembelian online berdasarkan rasionalitas.

Apabila dilihat dari dua sudut pandang yang berbeda yaitu secara statistik maupun secara lingkup pemasaran, maka secara statistik shopping lifestyle tidak berpengaruh terhadap keputusan pembelian produk online pada wanita bekerja namun dari hasil kuesioner yang diisi oleh responden menyatakan bahwa banyak responden yang menyatakan setuju dengan pernyataan yang diberikan. Hal ini berarti masih memungkinkan untuk marketer dapat mempertahankan stimulasi-stimulasi pemasaran dalam strategi penjualan mereka. Hanya saja pemasar harus dapat mengatasi hal ini, pemikiran dan sikap rasional seorang konsumen harus diperhatikan dalam strategi penjualan.

Hasil penelitian ini secara empiris membuktikan bahwa media sosial Instagram berpengaruh signifikan terhadap keputusan pembelian produk online. Hal ini menunjukkan pemakaian Instagram yang semakin tinggi maka semakin tinggi pula keputusan pembelian produk secara online begitu juga sebaliknya. Hasil penelitian dengan SPSS terlihat bahwa thitung > ttabel yaitu 3,652>1,66071 dan nilai sig. $0,000<0,05$. Dengan demikian hipotesis dalam penelitian ini yaitu $\mathrm{H} 2$ diterima. Hasil penelitian ini mendukung hasil penelitian dari Fitria (2015) yang menyatakan bahwa media sosial Instagram berpengaruh terhadap keputusan pembelian namun menolak hasil dari penelitian Mileva \& Fauzi (2018).

Hal ini berarti menandakan bahwa minat konsumen terhadap media sosial terus meningkat seiring dengan meningkatnya pemakaian internet dimasa kini. Pemasar diharapkan untuk mengikuti perkembangan zaman dalam memasarkan produk dan meningkatkan komunikasi serta pendekatan kepada konsumen melalui media sosial. Media sosial juga tidak hanya digunakan oleh perusahaan atau pelaku bisnis besar saja namun para pelaku bisnis skala kecil terbantu dengan adanya media sosial sebagai sarana promosi yang minim biaya.

\section{Kesimpulan}

Berdasarkan dari hasil analisis yang telah dilakukan, maka dapat ditarik kesimpulan sebagai berikut:

1. Shopping Lifestyle dan media sosial Instagram secara simultan berpengaruh signifikan terhadap keputusan kembelian online pada wanita bekerja di Banjarmasin.

2. Shopping Lifestyle tidak berpengaruh secara signifikan terhadap keputusan pembelian produk online pada wanita bekerja di Banjarmasin.

3. Media Sosial Instagram tidak berpengaruh secara signifikan terhadap keputusan pembelian produk online pada wanita bekerja di Banjarmasin.

Terdapat beberapa keterbatasan dalam penelitian ini yaitu :

- Penelitian ini memiliki jumlah sampel yang cendereung kecil disertai keterbatasan waktu yang ada

- Penelitian ini hendaknya tidak hanya dilakukan dengan pembagian kuesioner dan wawancara biasa saja namun hendaknya dilakukan dengan deep interview atau wawancara yang mendalam dengan responden agar responden lebih memahami isi dari butir pertanyaan dan lebih dalam lagi dalam mengetahui hal apa saja yang ada pada benak responden berkenaan variabel-variabel yang diteliti.

Oleh karena itu saran untuk penelitian kedepan adalah : (1) Pada penelitian ini Shopping Lifestyle tidak berpengaruh terhadap pembelian produk online wanita bekerja di Banjarmasin. Kemungkinan konsumen tidak serta merta melakukan pembelian hanya berdasarkan dorongan gaya hidup berbelanja semata, sisi rasionalitas konsumen ternyata turut mempengaruhi pola berbelanja mereka. Konsumen menyadari bahwa pengaruh pendapatan 
berkaitan dengan planned purchase yang dilakukan oleh konsumen wanita secara online. Hal ini juga dapat menjadi masukan untuk penelitian berikutnya. (2) Penelitian berikutnya dapat melakukan penelitian menggunakan variabel lainnya selain variabel yang diteliti diatas serta penelitian dengan menggunakan media sosial lainnya.

\section{DAFTAR PUSTAKA}

Andini, Intan \& Wardoyo. 2017. Faktor-Faktor Yang Berpengaruh Terhadap Keputusan Pembelian Secara Online Pada Mahasiswa Universitas Gunadarma.

Arikunto, Suharsimi. 2009. Prosedur Penelitian Suatu Pendekatan Praktik.Bina Aksara : Yogyakarta.

Fitria, Eva Melita. 2015. Dampak Online Shop di Instagram dalam Perubahan Gaya Hidup Konsumtif Perempuan Shopaholic di Samarinda. ISSN 0000-0000, ejournal.ilkom.fisipunmul.org.

Kosyu, Dayang Asning, et.al. 2014. Pengaruh Hedonic Shopping Motives Terhadap Shopping Lifestyle dan Impulse Buying (Survei pada Pelanggan Outlet Stradivarius di Galaxy Mall Surabaya). Jurnal Administrasi Bisnis (JAB)|Vol. 14 No. 2 September 2014.

Kotler, Philip and Kevin Lane Keller. 2016. Marketing Managemen, 15th Edition, Pearson Education,Inc.

Mileva, Lubiana \& Achmad Fauzi. 2018. Pengaruh Sosial Media Marketing Terhadap Keputusan Pembelian (Survei Online pada Mahasiswa Sarjana Jurusan Ilmu Administrasi Bisnis Angkatan 2014/2015 Fakultas Ilmu Administrasi Universitas Brawijaya yang Membeli Starbucks Menggunakan LINE.

Solis, Brian. (2011). Engage: The Complete Guide for Brands and Business to Build Cultivate andMeasure Success on The Web. New Jersey: John Wiley \& Sons

Sugiyono. 2013. Statistika Untuk Peneltian. Alfabeta : Bandung

Tirmizi, M.A. (009. An Empirical Study of Consumer Impulse Buying Behaviour in Local Markets. European Journal of Scientific Research, Vol 28(4), 522-532

Umboh, Zefanya. Lisbeth Mananeke \& Reitty Samadi. 2018. Pengaruh Shopping Lifestyle, Fashion Involvement Dan Sales Promotion Terhadap Impulse Buying Behaviour Konsumen Wanita Di MTC Manado.

www.databoks.katadata.co.id

www. Instagram.com 